\title{
The Nile River Basin: A Case Study in Surface Water Conflict Resolution
}

\author{
M. El-Fadel,* Y. El-Sayegh, K. El-Fadl, and D. Khorbotly
}

\begin{abstract}
The Nile, shared by 10 river basin countries, is the main vital water artery in the North Eastern region of Africa. The river has two main tributaries: the White Nile originating in Burundi, and the Blue Nile rising in Ethiopia. These are joined by the Atbara River north of Khartoum, Sudan. To date, the prevailing water policy regulating the distribution of water among the countries of the Nile basin is a bilateral 1959 agreement attributing the largest share of the river's flow to Egypt, the downstream, noncontributing country, with the rest allocated to Sudan, leaving other countries in the Nile watershed without specific shares. The high rate of population growth in the region propels governments to continuously seek food, and thus water security, to match increasing demand. Agricultural development in other basin countries could be enhanced with a more adequate distribution of water resources. Measures have been proposed to alleviate potential water shortages, including improved utilization of water in Egypt, and construction of numerous dams and canals. There are, however, disagreements with particular countries rejecting or accepting these plans depending on which country will benefit most. The objective of this paper is to present a decision case study to be taken by an international committee that should set strategies for the resolution of the water conflict through the harmonious exploitation of the Nile. The case study targets a course of education at the graduate or senior undergraduate level based on water resources issues impacting stability in the region.
\end{abstract}

A SUFFICIENT AND RELIABLE FRESHWATER SUPPLY is essential for protecting human health, supporting food production, preserving ecosystems, sustaining economic development, and providing vital goods and services such as hydroelectric power. However, water security is constantly threatened with increases in population, the misuse and contamination of water resources, inefficient irrigation, as well as the heightened intensity and frequency of natural disasters, such as droughts and floods. Perhaps continued population growth represents the most serious threat to water adequacy, whereby a larger population leads to a higher water demand for food production and for domestic, municipal, and industrial uses. Not only does the amount of available freshwater per capita decrease as a country's population increases, but so does the amount received by other states sharing that resource. The latter situation is the result of dam construction or altering a watercourse for additional irrigation systems in a particular country, hence redistributing water allotments among sharing countries (Gleick,

Department of Civil and Environmental Engineering, American University of Beirut, Bliss St., P.O. Box 11-0236, Lebanon. Received 22 July 2002. *Corresponding author (mfadel@aub.edu.lb).

Published in J. Nat. Resour. Life Sci. Educ. 32:107-117 (2003). http://www.JNRLSE.org

(C) American Society of Agronomy

677 S. Segoe Rd., Madison, WI 53711 USA
2000). The drive to exploit shared water supplies triggers animosities among countries and has been noted as one of the most urgent political issues on the United Nations global agenda (Gardiner, 2000; Nileriver.com, 2001; Population Action Int., 2001).

The risk of conflict is aggravated in the Middle East and North Africa (MENA) region, where rapid population growth is coupled with an arid climate (Population Action Int., 2001). In Africa, where poverty is a common phenomenon, 14 countries are currently experiencing water stress (their people receive the total equivalent of $<1500 \mathrm{~m}^{3} / \mathrm{yr}$ per capita), with another 11 expected to face a similar fate by the year 2025 , causing about $16 \%$ of the continent's population (the equivalent of 230 million people) to suffer from water shortages. In addition, the continent possesses 19 of the 25 countries in the world with the highest percentage of population without access to safe drinking water. Furthermore, the heavy reliance on agriculture, which accounts for $88 \%$ of the total water use, coupled with a lack of regional basin level planning, exacerbate the uneven distribution of water resources among countries (BBC, 1999; Gardiner, 2000; Karyabwite, 2000).

In this context, the vast Nile basin represents one of the critical, and perhaps the most important, shared water basins in Africa. Ten countries presently share its waters: Burundi, the Democratic Republic of Congo (DRC), Egypt, Eritrea, Ethiopia, Kenya, Rwanda, Sudan, Tanzania, and Uganda, of which the DRC and Eritrea lie to a lesser extent in the basin. Although these 10 countries represent $10 \%$ of Africa's landmass, they house $40 \%$ of the continent's population, of whom $70 \%$ reside in the Nile basin. Egypt, the most downstream country, has been the traditional user of the Nile, exploiting its waters almost exclusively. However, upstream countries have begun to consider controlling more of the Nile waters, in an attempt to initiate economic development and sustain their growing populations. Yet, the economic development sought by most countries of the Nile basin has been hindered by unresolved conflicts: Sudan and Burundi are enduring civil wars, Tanzania is threatened by famine, while volatility and internal and regional discord has limited the abilities of the DRC, Eritrea, Ethiopia, Rwanda, and Uganda to devise water development schemes (Varis, 2000; Nileriver.com, 2001; Nile Basin Initiative, 2002).

This article focuses on the conflict over the shared water resources of the Nile River and considers the decision of an international committee for its equitable distribution among the countries in the river's watershed. Based on the presented information, the committee (to be composed of top-level ministers) in coordination with the foreign ministers of all 10 countries (representatives from the United Nations and several NGO mediators) needs to develop a set of strategies for the

Abbreviations: BCM, billion cubic meters, DRC, Democratic Republic of Congo; GDP, gross domestic product; GNP, gross national product; IWRM, Integrated Water Resource Management; MENA, Middle East and North Africa; NBI, Nile Basin Initiative. 


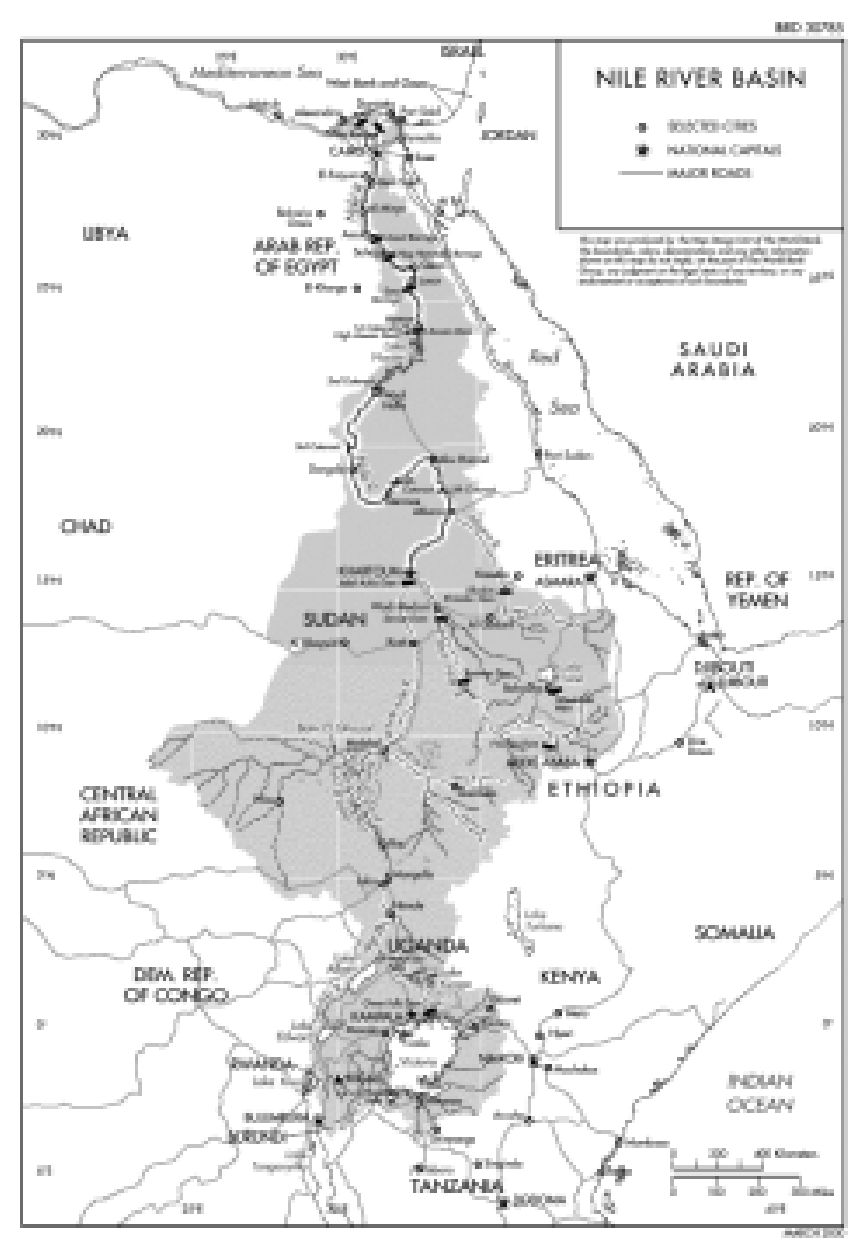

Exhibit 1. Map of the Nile River basin (Nile Basin Initiative, 2002) and status of water in 2025 (Karyabwite, 2000).

resolution of the water conflict issue and the development of an integrated water plan that allows for an equitable and efficient exploitation of the Nile. The article represents a case study that can be used by graduate or senior undergraduate students to role-play as opponents, supporters, and/or mediators in a conflict resolution situation.

\section{THE CASE}

Following the independence from colonialism, disputes between countries in the Nile River basin became inter-state and assumed internationally debatable dimensions. Agreements regulating the Nile River divided water between Egypt and Sudan, disregarding the needs of the remaining countries that are in increasing need for water to sustain their growing populations. These disadvantaged countries claim their right to equitable water distribution because the Nile represents the only renewable water resource in the region, hence leading to an ongoing debate regarding the most appropriate and efficient management strategy of its waters. Regional political instability and internal armed conflicts within the majority of the involved countries further amplify the problem. However, as the Nile basin countries recognize the dynamics of the population-water relationship, there remains ample opportunity to advance planning and diplomacy to overcome the conflict potential.
Exhibit 2. Nile basin repartition (Karyabwite, 2000).

\begin{tabular}{lcc}
\hline Country & Percentage of country in Nile basin & Percentage of total Nile basin \\
\hline Burundi & 47.6 & 0.4 \\
DRC $\dagger$ & 0.9 & 0.7 \\
Egypt & 32.6 & 10.5 \\
Eritria & 20.5 & 0.8 \\
Ethiopia & 32.4 & 11.7 \\
Kenya & 7.9 & 1.5 \\
Rwanda & 75.5 & 0.7 \\
Sudan & 79 & 63.6 \\
Tanzania & 8.9 & 2.7 \\
Uganda & 98 & 7.4 \\
\hline
\end{tabular}

$\dagger$ DRC $=$ Democratic Republic of Congo.

\section{The Nile River Basin}

The 6850-km long Nile is the world's longest river, and flows from south to north with a catchment basin covering approximately $10 \%$ of the African continent (Exhibit 1 ). The river spreads across 10 countries with an area of $3 \times 10^{6} \mathrm{~km}^{2}$ (Exhibit 2). Although all the waters in Burundi and Rwanda and more than half the waters in Uganda are produced within their boundaries, most of the water resources of Sudan and Egypt originate outside their borders: 77 and 97\%, respectively (FAO, 1997). About 94 billion cubic meters (BCM) flow annually to Lake Aswan, Egypt, yet only 0.4 BCM are released into the Mediterranean through the Rosetta, Damietta, and other main branches along its 40-km wide delta (Karyabwite, 2000; Varis, 2000; Nile Basin Initiative, 2002).

The river has three tributaries: the White Nile, the Blue Nile, and the Atbara. The upper White Nile ${ }^{1}$ originates in the East African highlands of Burundi (Exhibit 3), flows through the now submerged Owen Falls, Lake Kyoya, Kabalega (Murchisson), and Lake Mobuttu to drain into Lake Victoria. At least $50 \%$ of Lake Victoria's annual discharge (27 BCM) is lost to evaporation in the Sudd swamplands of Southern Sudan. The $1529 \mathrm{~km}$ long Blue Nile rises at a spring site upstream of Lake Tana in Ethiopia and provides more than $53 \%$ of the Nile's water. The Blue Nile flows west and then north to merge with the White Nile at Khartoum from where it flows $322 \mathrm{~km}$ northeast to join with the Nile's most northerly tributary, Atbara, which also originates on the Ethiopian highlands. From the Atbara confluence, the river flows through the Nubian Desert northward through Egypt and drains into the Mediterranean (Beschorner, 1992; Howell and Allan, 1994; Inventory of Conflict and Environ., 1997; Nile Basin Initiative, 2002).

A distinguishing feature of the Nile is that half of its course flows through countries with no effective rainfall (Exhibit 4). Nearly all of the river's water is generated on an area covering $20 \%$ of the basin, while the remainder is arid or semiarid regions with minimal water supplies and very large evaporation losses (Karyabwite, 2000).

\section{Socio-Economics of Nile Basin Countries}

Almost $40 \%$ of Africa's population (equivalent to approximately 300 million people), lives in the Nile basin and is projected to at least double by 2025 . Exhibit 5 presents popula-

\footnotetext{
${ }^{1}$ The Ruvyironza is considered to be the main source of the Nile River and is one of the higher branches of the Kagera River that flows northward from the Rwandan border before eventually becoming the White Nile (Nile Basin Initiative, 2002).
} 


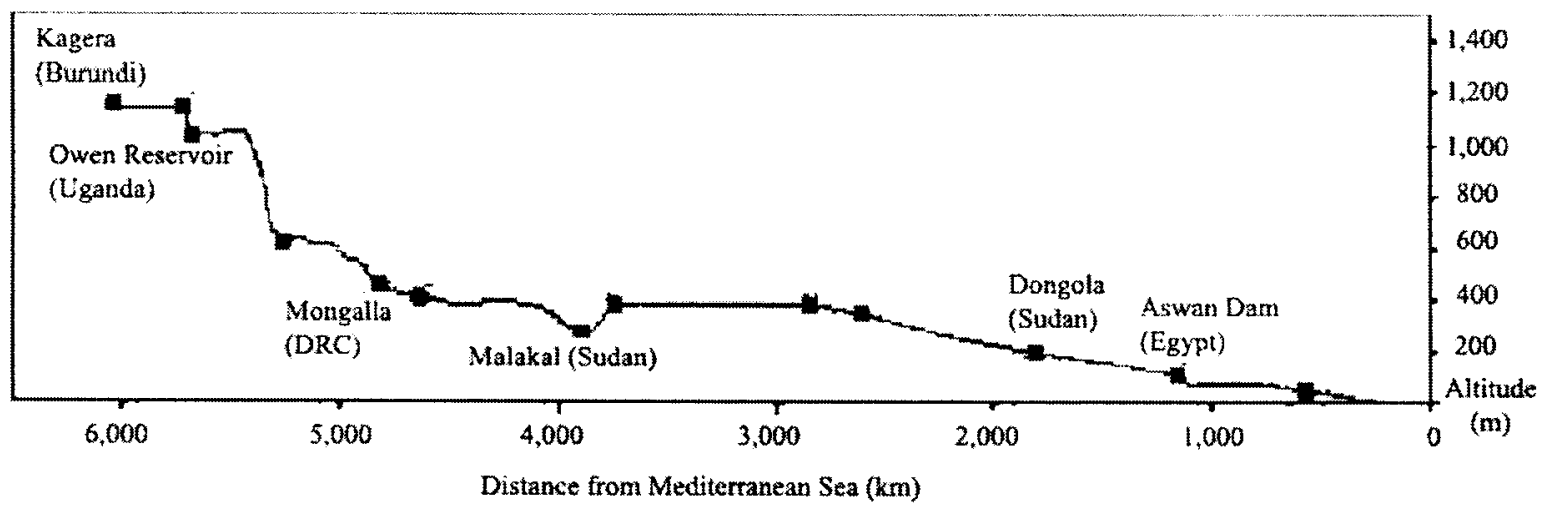

Exhibit 3. Nile river profile from Kagera to the Mediterranean Sea (adapted from Karyabwite, 2000).

tion and water use in the 10 countries for the year 2000. Due to the limited availability of renewable sources of water, population growth will decrease the available per capita water. Population distribution in the basin is dominated by a shift toward greater urbanization. For instance, the urban population in Burundi, Ethiopia, Rwanda, and Uganda is projected to more than double as a percentage of the total population. This redistribution presents implications for water management as urban populations generally consume more water per capita for domestic and industrial use than rural populations. Moreover, although urbanization can open opportunities for taking advantage of economies of scale in water delivery and sanitation, it also poses challenges of delivering water in remote areas, such as ensuring drinking water sanitation and appropriate wastewater treatment (Baecher et al., 2000).

The growth rates of gross domestic and gross national products (GDP and GNP) ${ }^{2}$ are uneven in the Nile basin (Exhibit 6). The GDP is considered a rough indicator of water demand because, with other things being equal, higher per capita GDP is associated with greater water demand. The sectoral composition of GDP is also an indicator of demand. Agricultural production consumes the largest amount of water per unit of GDP, followed by the midrange industrial sector and the least consumptive services sector. The relative growth of the sectors will influence future water demands and increased industrial activity may adversely impact water quality if pollution control measures are not implemented, monitored, and enforced. The GDP of basin countries exhibited a growth in the various sectors during the 1990s except in Burundi, Rwanda, and the DRC (Exhibit 7). This may indicate that, if and when the political situation stabilizes, the war-torn areas are likely to experience rapid economic recovery. Another important fact is that Uganda's high rate of industrial growth could eventually pose adverse effects on the water quality of the upper basin (Baecher et al., 2000).

Additional development projects along the Nile are postulated to help the countries meet their growing food supply demands. Such progress may be achieved through the expansion of agriculture as most of the countries are not yet operating at their full irrigation potential (Exhibit 8). However, this will

\footnotetext{
${ }^{2}$ Gross domestic product (GDP) is the value of total final outputs produced with labor or capital located in a country during a given year, whereas gross national product (GNP) is the value of all final goods and services produced in a year with labor or capital owned by the residents of a particular country (Samuelson and Nordhaus, 1998).
}

Exhibit 4. Water resources and availability per person (Karabywite, 2000).

\begin{tabular}{|c|c|c|c|c|c|}
\hline Country & $\operatorname{IRWR} \dagger$ & ARWR $\ddagger$ & $\begin{array}{l}\text { Dependency } \\
\text { ratio } \S\end{array}$ & $\begin{array}{c}\text { Per capita IRWR } \\
\text { in } 1994\end{array}$ & $\begin{array}{c}\text { Per capita } \\
\text { ARWR in } 1994\end{array}$ \\
\hline & \multicolumn{2}{|c|}{$\mathrm{km}^{3} / \mathrm{yr} \longrightarrow$} & $\%$ & \multicolumn{2}{|c|}{$\longrightarrow \mathrm{m}^{3} /$ inhabitant $\longrightarrow$} \\
\hline Burundi & 3.6 & 3.6 & 0 & 579 & 563 \\
\hline DRCI & 935 & 1019 & 8.2 & 21973 & 23211 \\
\hline Egypt & 1.7 & 58.3 & 96.9 & 29 & 926 \\
\hline Eritria & 2.8 & 8.8 & 68.2 & 815 & 2492 \\
\hline Ethiopia & 110 & 110 & 0 & 2059 & 1998 \\
\hline Kenya & 20.2 & 30.2 & 33.1 & 739 & 1069 \\
\hline Rwanda & 6.3 & 6.3 & 0 & 833 & 792 \\
\hline Sudan & 35 & 88.5 & 77.3 & 1279 & 3150 \\
\hline Tanzania & 80 & 89 & 10.1 & 2773 & 2998 \\
\hline Uganda & 39.2 & 66 & 40.9 & 1891 & 3099 \\
\hline
\end{tabular}

$\dagger$ IRWR, Internal renewable water resources.

† ARWR, Actual renewable water resources.

\& Dependency ratio represents the extent to which the supply of a country's renewable water resources is dependent on sources external to its political boundaries and can be calculated using the equation (ARWR - IRWR)/ARWR $\times 100$. II DRC, Democratic Republic of Congo.

only be realized if water allocation is managed equitably and efficiently.

\section{Conflicts in the Nile Basin}

The Nile basin has experienced a long period of conflict spanning the ancient Egyptian civilizations, the colonial reign, and continuing to the modern day. Historically, the river provided the Egyptians with almost all their fresh water, and has long been regarded as the cultural symbol of Egypt dating back to the times of the Pharaohs. The Egyptians were always concerned that the Nile's waters may stop reaching them and, as a result, have tried to bring the entire Nile valley under their rule, invading Sudan during the reign of Queen Sheba, the Roman rule of Nero, and at numerous other instances (Inventory of Conflict and Environ., 1997; Nileriver.com, 2001).

Colonialism marked the beginning of the modern history of the Nile conflict in the 20th century (Exhibit 9) by realizing the significance of the Nile water for the prosperity of the colonies, particularly Egypt. Upon reconquering Sudan in 1898, the British removed vegetation that was obstructing navigation along the river, creating alternative drainage paths to divert and improve the flow. Signing an agreement with Ethiopia in 1902 was necessary to ensure the security of the water supply, since Ethiopia provides $80 \%$ of the Nile water and the British had no control over the Ethiopian portion. Britain also had to negotiate with France and Italy to prevent 
Exhibit 5. Population and water use in the Nile basin countries for the year 2000 (FAO, 2000).

\begin{tabular}{|c|c|c|c|c|c|c|c|c|c|c|}
\hline \multirow[t]{2}{*}{ Country } & \multirow[t]{2}{*}{ Total population } & \multirow[t]{2}{*}{ Rural population } & \multirow[t]{2}{*}{ Urban population } & \multicolumn{2}{|c|}{ Agricultural water use } & \multicolumn{2}{|c|}{ Domestic water use } & \multicolumn{2}{|c|}{ Industrial water use } & \multirow{2}{*}{$\frac{\text { Total water use }}{\mathrm{km}^{3} / \mathrm{yr}}$} \\
\hline & & & & $\mathrm{km}^{3} / \mathrm{yr}$ & $\%$ & $\mathrm{~km}^{3} / \mathrm{yr}$ & $\%$ & $\mathrm{~km}^{3} / \mathrm{yr}$ & $\%$ & \\
\hline Burundi & 6.356 & 5.787 & 0.570 & 0.19 & 82 & 0.04 & 17 & 0.00 & 1 & 0.23 \\
\hline $\mathrm{DRC} \dagger$ & 50.948 & 35.521 & 15.427 & 0.11 & 31 & 0.19 & 52 & 0.06 & 16 & 0.36 \\
\hline Egypt & 67.884 & 37.195 & 30.690 & 53.85 & 78 & 5.23 & 8 & 9.57 & 14 & 68.65 \\
\hline Eritrea & 3.659 & 2.973 & 0.686 & 0.29 & 95 & 0.01 & 4 & 0.00 & 1 & 0.30 \\
\hline Ethiopia & 62.908 & 51.805 & 11.102 & 2.47 & 93 & 0.03 & 1 & 0.15 & 6 & 2.65 \\
\hline Kenya & 30.669 & 20.517 & 10.152 & 1.01 & 64 & 0.47 & 30 & 0.10 & 6 & 1.58 \\
\hline Rwanda & 7.609 & 7.141 & 0.468 & 0.03 & 39 & 0.04 & 48 & 0.01 & 14 & 0.08 \\
\hline Sudan & 31.095 & 19.863 & 11.232 & 36.07 & 97 & 0.99 & 3 & 0.26 & 1 & 37.31 \\
\hline Tanzania & 35.119 & 23.571 & 11.548 & 1.85 & 93 & 0.12 & 6 & 0.03 & 1 & 2.00 \\
\hline Uganda & 23.300 & 20.002 & 3.298 & 0.12 & 39 & 0.13 & 45 & 0.05 & 15 & 0.30 \\
\hline
\end{tabular}

$\dagger$ DRC, Democratic Republic of Congo.

Exhibit 6. The GDP and GNP growth in riparian countries (Baecher et al., 2000).

\begin{tabular}{lccc}
\hline Country & GDP 1998 & $\begin{array}{c}\text { Avg. annual GDP growth } \\
\text { from 1994 to 1998 }\end{array}$ & GNP per capita, 1998 \\
\hline & million $\$$ & $\%$ & $\$$ \\
Burundi & 859 & -2.5 & 173 \\
DRC $\dagger$ & 6101 & -5.6 & 110 \\
Egypt & 68743 & 4.1 & 1250 \\
Eritria & 681 & 5.2 & 198 \\
Ethiopia & 6716 & 4.1 & 100 \\
Kenya & 9791 & 1.7 & 350 \\
Rwanda & 1813 & -3.6 & 230 \\
Sudan & 8383 & 7.3 & 290 \\
Tanzania & 5552 & 2.9 & 210 \\
Uganda & 6944 & 7.1 & 310
\end{tabular}

$\dagger$ DRC, Democratic Republic of Congo.

Exhibit 7. Composition of the GDP and sectoral rowth rates during 1990-1998 (Baecher et al., 2000).

\begin{tabular}{|c|c|c|c|c|c|c|}
\hline \multirow[b]{2}{*}{ Country } & \multicolumn{2}{|c|}{ Agriculture } & \multicolumn{2}{|c|}{ Industry } & \multicolumn{2}{|c|}{ Services } \\
\hline & $\begin{array}{l}\% \text { of } \\
\text { GDP }\end{array}$ & $\begin{array}{l}\text { Growth } \\
\text { rate }\end{array}$ & $\begin{array}{l}\% \text { of } \\
\text { GDP }\end{array}$ & $\begin{array}{l}\text { Growth } \\
\text { rate }\end{array}$ & $\begin{array}{l}\% \text { of } \\
\text { GDP }\end{array}$ & $\begin{array}{l}\text { Growth } \\
\text { rate }\end{array}$ \\
\hline Burundi & 52.4 & -1.8 & 17.1 & -6.3 & 30 & -1.9 \\
\hline $\mathrm{DRC}^{\dagger}$ & 60.4 & 2.8 & 17.3 & -13.3 & 20.9 & -14.6 \\
\hline Egypt & 14.9 & 2.8 & 30.4 & 4.2 & 47.1 & 4 \\
\hline Eritria & NA $\neq$ & NA & NA & NA & NA & NA \\
\hline Ethiopia & NA & NA & NA & NA & NA & NA \\
\hline Kenya & 26.1 & 1.1 & 13.4 & 2 & 45.7 & 3.6 \\
\hline Rwanda & 35.2 & -5.0 & 23.6 & -1.8 & 39.2 & -3.1 \\
\hline Sudan & NA & NA & NA & NA & NA & NA \\
\hline Tanzania & 42.4 & 3.6 & 14.2 & 1.9 & 35.2 & 2.3 \\
\hline Uganda & 40.3 & 3.6 & 15.7 & 12.1 & 33.7 & 8.2 \\
\hline
\end{tabular}

$\dagger$ DRC, Democratic Republic of Congo.

$\$$ NA, not available.

their intervention with its dominance over the Nile basin. In 1929, Britain sponsored the Nile Water Agreement for water allocation to support Egyptian planned developments on the river. The bilateral agreement divided the Nile's water between the two most downstream countries, without consulting any of the other involved parties. Egypt was provided with the monopoly over the resource and Sudan was allocated a mere 4 BCM, approximately 5\% of the river's flow (allAfrica.com, 1999; Inventory of Conflict and Environ., 1997).

The most comprehensive treaty that addresses sharing the Nile's water remains the 1959 Water Agreement on "the full utilization of the Nile water" between Egypt and Sudan. The treaty established the average annual Nile flow at about 84 BCM, measured at Aswan high dam in Egypt, and estimated annual water loss due to evaporation and other factors at 10 BCM. The losses were deducted from the Nile yield of 84
Exhibit 8. Irrigation potential and water requirements in selected Nile basin countries (FAO, 1997).

\begin{tabular}{|c|c|c|c|}
\hline Country & $\begin{array}{c}\text { Area } \\
\text { irrigated }\end{array}$ & $\begin{array}{l}\text { Irrigation } \\
\text { potential } \dagger\end{array}$ & Water requirements \\
\hline & \multicolumn{2}{|c|}{$\longrightarrow \mathrm{km}^{2} \longrightarrow$} & \\
\hline Burundi & NA $\ddagger$ & 1050 & \multirow{2}{*}{$\begin{array}{l}\text { Improving the drainage network in part of } \\
\text { the swamp areas, combined where pos- } \\
\text { sible with an irrigation network, would } \\
\text { allow year-round cultivation in the two } \\
\text { countries }\end{array}$} \\
\hline Rwanda & NA & 1500 & \\
\hline Ethiopia & 250 & 22200 & $\begin{array}{l}\text { Requires regulation of surface runoff and } \\
\text { the construction of dams }\end{array}$ \\
\hline $\begin{array}{l}\text { Kenya } \\
\text { Lake Victoria Basin }\end{array}$ & 60 & 1800 & $\begin{array}{l}\text { Dams and water transfers to other (sub) } \\
\text { basins are proposed }\end{array}$ \\
\hline Tanzania & NA & 300 & $\begin{array}{l}\text { Requires the construction of considerable } \\
\text { water conveyance works }\end{array}$ \\
\hline Uganda & 55.5 & 2020 & $\begin{array}{l}\text { Necessitates major works such as storage, } \\
\text { river regulation, and large-scale } \\
\text { drainage }\end{array}$ \\
\hline
\end{tabular}

† Irrigation potential is the area that can potentially be irrigated as determined by the physical resources, soil and water, combined with the irrigation water requirements as determined by the cropping patterns and climate.

+ NA, not available.

$\mathrm{BCM}$ and the remaining water was divided among Egypt and Sudan as 55.5 and 18.5 BCM, respectively. Sudan was to construct projects to contribute to the Nile's flow by preventing evaporation losses in the Sudd swamps of the White Nile, with costs and benefits divided equally between the two countries. The projects included the Roseires $\mathrm{Dam}^{3}$ on the Blue Nile, the Jonglei canal, and other irrigation and hydroelectric power generation projects. Egypt was entitled to construct the Aswan High Dam to manage the yearly floods of the river, reduce sediment deposition in the delta area, and reap its hydroelectric power. The parties decided to handle claims over the Nile by other basin countries by removing any amount that these countries may be entitled to in equal parts from both Egypt's and Sudan's shares (Whittington and Guariso, 1983; Inventory of Conflict and Environ., 1997; Nile Basin Initiative, 2002).

The DRC, the East African countries, and Ethiopia were not consulted over the final terms of the 1959 agreement and their water rights have not been explicitly mentioned (Howell and Allan, 1994). As a result, these countries have been invalidating the agreement and requesting the renegotiation of its contents to take their own interests into account (George,

\footnotetext{
${ }^{3}$ Eighty percent of Sudan's electricity is currently produced by hydroelectric schemes at Roseires and Sennar, where the dams supply irrigation water for more than $10000 \mathrm{~km}^{2}$ of the Gezira plain (Nile Basin Initiative, 2002).
} 
Exhibit 9. Summary of major events and agreed upon or conflicting issues in the Nile basin.

\begin{tabular}{|c|c|c|}
\hline Year & Agreed issues & Conflicting issues \\
\hline $1704 \dagger$ & Ethiopia and Egypt & King of Ethiopia threatens Egyptian Pasha to cut off the Nile. \\
\hline $1898 \ddagger$ & Egypt, France, and Britain & $\begin{array}{l}\text { A French expedition attempted to gain control of the headwaters of } \\
\text { the White Nile. } \\
\text { Military conflict nearly ensued between Britain and France. The } \\
\text { incident "dramatized Egypt's vulnerable dependence on the Nile, } \\
\text { and fixed the attitude of Egyptian policy-makers ever since." The } \\
\text { parties ultimately negotiated a settlement of the dispute. }\end{array}$ \\
\hline
\end{tabular}

$\begin{array}{ccc}1902 \dagger & \text { Britain and Ethiopia } & \begin{array}{c}\text { Agreement was signed to limit Ethiopian intervention } \\ \text { with the Nile waters. } \\ \text { Nile Water Treaty: Britain provided Egypt with the monopoly } \\ \text { over the river, allocating only } 4 \text { billion cubic meters to Sudan. }\end{array}\end{array}$

$1958 \ddagger \quad$ Egypt and Sudan over the river, allocating only 4 billion cubic meters to Sudan
ove Water Treaty: Britain provided Egypt with the monopoly

Egypt sends an unsuccessful military expedition into disputed territory amidst pending negotiations over the Nile waters.

$1958 \dagger \quad$ Report on the Nile Valley Plan issued. A 50-yr hydrological study made on the non-Ethiopian portions of the Nile basin that suggests different alternatives to increase the amount of water reaching Egypt, such as the Jonglei Canal (conflicts with Ethiopia prevented the inclusion of the Ethiopian section).

$1959 \S \amalg$ Egypt and Sudan $\quad$ Nile Water Treaty signed when pro-Egyptian government elected in Sudan. Water Agreement on "the full utilization of the Nile water."

$1959 \dagger \quad$ Construction of the Aswan High Dam commenced (funded by the Soviet Union after the USA and the World Bank refused to fund the project). $\dagger$

1960s $\dagger \quad$ More than 100000 Nubians forced to move from northern Sudan and southern Egypt due to development projects of the 1959 treaty.

$1968+\dagger \quad$ Aswan High Dam completed. The dam is $100 \mathrm{~m}$ high, $1 \mathrm{~km}$ thick, and stretches $4 \mathrm{~km}$ across the Nile's trajectory. The reservoir formed behind it, named Lake Nasser, is the second largest man-made lake in the world, reaching $600 \mathrm{~km}$ long and $50 \mathrm{~km}$ wide in some parts. $\dagger$

1970s $\dagger \quad$ Sudan and Egypt began the joint construction of the Jonglei canal (funded by the World Bank).

$1978 \ddagger \quad$ Egypt and Ethiopia

Ethiopia's proposed construction of dams on the headwaters of the Blue Nile rekindles Egyptian animosities.

$1979 \div \quad$ Egypt and Ethiopia

Anwar Sadat declared: "The only matter that could take Egypt to war again is water" (concerning Ethiopia's proposed water development projects).

$1983 \dagger \quad$ Construction of the Jonglei Canal ceased (100 km short of completion) due to acts of rebellion in Sudan, foregoing more than $\$ 100$ million.

1990s $\dagger \quad$ Egypt blocked an African Development Bank loan to Ethiopia for a project, which might have reduced the flow into Egypt.

$1992+5 \quad$ The Technical Cooperation Committee for the Promotion of the Development and Environmental Protection of the basin (TECCONILE) was established. It was intended to promote the development of infrastructure, capacity building, techniques for water resources management and the formulation of national master plans in the short term, and the development of the basin in an integrated and sustainable manner through basin-wide cooperation and the determination of equitable water allocation in the long run.

$1994 \dagger \quad$ Egypt and Sudan

Egypt planned and then cancelled an air raid on Khartoum, where a dam was being built.

$1995 \dagger \quad$ Egypt and Sudan

Increased tensions over the attempted assassination of President Mubarak.

Border clashes became common, threatening serious conflict.

$1997 \S$ Nile 2002 Conference held in Addis Ababa, Ethiopia. The need to hold fresh negotiations and fair agreements was stressed to enable all basin countries to benefit from the Nile.

$1999 \S$ Nile 2002 Conference held in Cairo. Emphasis was placed on the allocation and conservation of water resources in the basin. The status quo was not challenged, Ethiopia was under-represented, with majority of papers presented by Egyptians.

$2001 \S$ Egypt, Sudan, and Ethiopia established the Eastern Nile Subsidiary Action Plan (ENSAP), coordinating their efforts to execute joint and independent irrigation, hydroelectric power, and water management projects in the basin.

† Inventory of Conflict and Environ., 1997

$\$$ Gleick, 2000

$\S$ allAfrica.com, 1999

II The Reporter, 1999

\# Stratfor, 200

$\dagger$ Varis, 2000

㭋 Karyabwite, 2000

$\S \S$ Addis Tribune, 2001
1998). Although Ethiopia possesses a population nearly the size of Egypt's, the latter continues to argue that the bilateral agreement is irrevocable since its population growth is likely to double by 2025 , and access to this volume of water is vital to its ability to support the growing population (George, 1998).

Furthermore, Ethiopia has been left out of negotiations because the two lower basin countries have traditionally claimed that the country can sustain itself solely through rainfed agriculture. However, successive drought-induced famines in the last three decades have proven otherwise. Despite its substantial natural resources and potential for agricultural production, Ethiopia is one of the poorest countries in the world with food insecurity as a major problem. It has so far been able to develop only 0.04 and $2 \%$ of its irrigation and hydropower potential through its share of the Nile system. One avenue for moving toward poverty reduction and increased food security may be through developing the country's vast arable land, which requires more water. Egypt feels threatened by the potential demands for more water. In this context, even the construction of small dams using only $0.5 \mathrm{BCM}$ of the river's annual flow triggered Egypt to use its diplomatic influence in the 1990s to block an African Development Bank loan to Ethiopia (Inventory of Conflict and Environ., 1997).

Inevitably, the political relations between the countries in the basin influence the water negotiations to a large extent. Egypt is particularly interested in promoting Sudanese stability as internal conflicts in Sudan represent the main threat to the Nile basin water utilization patterns. Also, the Blue Nile represents the source of the Egyptian-Ethiopian dispute, as Ethiopia demands its natural rights to exploit its waters, over which Egypt has assumed total control.

Recent efforts toward cooperation were portrayed in 1998 when all countries, except Eritrea, joined in a dialogue to create a regional partnership to facilitate the common pursuit of 
Exhibit 10. Selected projects under the Nile Basin Initiative (Nile Basin Initiative, 2002).

\begin{tabular}{|c|c|c|c|}
\hline Projects & Objectives & Major components & Proposed outputs \\
\hline $\begin{array}{l}\text { Nile Trans-boundary } \\
\text { Environmental Action }\end{array}$ & $\begin{array}{l}\text { Provide a strategic framework for } \\
\text { environmentally sustainable development } \\
\text { of the Nile River basin. } \\
\text { - Support basin-wide environmental action } \\
\text { linked to trans-boundary issues in the context } \\
\text { of the Nile Basin Initiative strategic action } \\
\text { program. }\end{array}$ & $\begin{array}{l}\text { - Institutional strengthening to facilitate } \\
\text { regional cooperation. } \\
\text { - Community-level land and water conservation. } \\
\text { - Environmental education and awareness. } \\
\text { - Wetlands and biodiversity conservation. } \\
\text { - Basin-wide water quality monitoring. }\end{array}$ & $\begin{array}{l}\text { - Enhanced regional cooperation on trans-boundary } \\
\text { environmental and natural resource management } \\
\text { issues. } \\
\text { - Capacity and support for local-level action on } \\
\text { land, forest, and water conservation. } \\
\text { - Awareness of civil society through environmental } \\
\text { education programs and networking of univer- } \\
\text { sities and research institutions. } \\
\text { - Sustainable management of wetlands and estab- } \\
\text { lishment of wetlands management programs. } \\
\text { - Standard basin-wide analytical methods for water } \\
\text { quality measurements established and monitoring } \\
\text { of trans-boundary relevant hotspots initiated. En- } \\
\text { hanced capacity for monitoring efforts and } \\
\text { pollution prevention. }\end{array}$ \\
\hline $\begin{array}{l}\text { Efficient Water Use for } \\
\text { Agricultural Production }\end{array}$ & $\begin{array}{l}\text { Provide a sound conceptual and practical } \\
\text { basis to increase availability and efficient } \\
\text { use of water for agricultural production. }\end{array}$ & $\begin{array}{l}\text { - Regional consultations and training. } \\
\text { - Demonstrations/pilots and basin-wide } \\
\text { exchange of experience. }\end{array}$ & $\begin{array}{l}\text { - Improved enabling environment for sustainable } \\
\text { watershed management and increased produc- } \\
\text { tivity. } \\
\text { - Improved enabling environment for community } \\
\text { managed irrigation development and increased } \\
\text { agricultural production. } \\
\text { - Options for reforms in public managed irrigation } \\
\text { reviewed and appropriate pilot projects that } \\
\text { demonstrate improved system performance im- } \\
\text { plemented. Options for irrigation development } \\
\text { explored. }\end{array}$ \\
\hline $\begin{array}{l}\text { Water Resources Planning } \\
\text { and Management }\end{array}$ & $\begin{array}{l}\text { Enhance the analytical capacity for basin- } \\
\text { wide perspective to support the development, } \\
\text { management, and protection of Nile basin } \\
\text { waters. }\end{array}$ & $\begin{array}{l}\text { - Water policy good practice guides and support. } \\
\text { - Project planning and management good; } \\
\text { practice guides and support. } \\
\text { - Development of a decision support system } \\
\text { (DSS) for the Nile basin. }\end{array}$ & $\begin{array}{l}\text { - Support for water policy development and imple- } \\
\text { mentation and strengthening national capacities. } \\
\text { - Building and enhancing human capacity and in- } \\
\text { stitutional support to facilitate water resources } \\
\text { planning and management on regional, subre- } \\
\text { gional, and national levels. }\end{array}$ \\
\hline
\end{tabular}

sustainable development and management of the Nile's waters. They jointly adopted an inclusive transitional mechanism for cooperation until a permanent cooperative framework is established. In May 1999 the overall process was officially named the Nile Basin Initiative (NBI) (Nile Basin Initiative, 2002). Exhibit 10 provides examples of current activities and projects supervised by the NBI to create an enabling environment of cooperation, action, and investments with respect to the management of the Nile's waters.

\section{THE LEGAL ASPECT}

International water laws address the basic interests of the international community to maintain global peace and security. Their application nevertheless remains limited, since they still lack maturity, sophistication, clarity, and enforceability, and hence are rendered powerless when a country chooses to ignore the laws in question.

In theory, international waters are to be distributed fairly and rationally among countries within the river's watershed. The Helsinki Rules on the Uses of the Waters of International Rivers, adopted by the International Law Association in 1966, provide a guideline for the proper utilization and administration of international rivers in cases where no specific agreements or traditional understanding prevail (Int. Law Assoc., 1967). It sets equitable allotments to countries in a basin not by equal shares but according to specific variables that help prioritize their various needs (Exhibits 11 and 12) such as: (i) topography of the basin, particularly the size of the river's

Exhibit 11. Country data with respect to selected priority variables under the Helsinki Rules.

\begin{tabular}{|c|c|c|c|c|c|c|c|c|c|c|c|}
\hline \multirow{3}{*}{ Country } & \multirow{3}{*}{ Climate } & \multirow{3}{*}{$\frac{\text { Rainfall }}{\mathrm{mm} / \mathrm{yr}}$} & & & \multicolumn{4}{|c|}{ Social and economic needs $\dagger$} & \multicolumn{2}{|c|}{ Dependence on agriculture } & \multirow{3}{*}{$\begin{array}{l}\text { Availability of } \\
\text { other resources }\end{array}$} \\
\hline & & & \multicolumn{2}{|c|}{$\begin{array}{c}\text { Present } \\
\text { utilization }\end{array}$} & $\begin{array}{l}\text { Population } \\
\text { growth }\end{array}$ & $\begin{array}{l}\text { Agricultural } \\
\text { growth }\end{array}$ & $\begin{array}{c}\text { Life } \\
\text { expectancy }\end{array}$ & $\begin{array}{l}\text { Infant } \\
\text { mortality }\end{array}$ & $\begin{array}{l}\% \text { of food } \\
\text { imports }\end{array}$ & $\begin{array}{l}\text { Agriculture } \\
\text { as \% of GDP }\end{array}$ & \\
\hline & & & $\mathrm{BCM}$ & $\%$ of flow & $\longrightarrow$ & $\%$ & $\mathrm{yr}$ & $\begin{array}{l}\text { infant deaths/ } \\
1000 \text { live births }\end{array}$ & & & \\
\hline Burundi & tropical & $1000-1500$ & NA & NA & 2.9 & 1.7 & 49.5 & 110 & 18 & 56 & none \\
\hline DRC $§$ & tropical & $1500-2000$ & NA & NA & 1.9 & 2.7 & 61.6 & 57 & 20 & 30 & minerals, hydropower, oil \\
\hline Egypt & desert & $<200$ & $59-60$ & 79 & 1.9 & 2.7 & 61.6 & 57 & 31 & 17 & oil, Suez Canal industry \\
\hline Ethiopia & NA & NA & $<0.6$ & 0.5 & 2.9 & -2.1 & 47 & 122 & 17 & 41 & gas, hydropower \\
\hline Kenya & $\begin{array}{l}60 \% \text { tropical, } \\
30 \% \text { savannah, } \\
30 \% \text { semi-arid }\end{array}$ & NA & NA & NA & 3.8 & 3.4 & 61 & 64 & 10 & 28 & hydropower, tourism \\
\hline Rwanda & tropical & $1000-1500$ & NA & NA & 3.4 & -1.1 & 52 & 112 & 9 & 38 & none \\
\hline Sudan & desert/savannah & $400-1500$ & 16 & 20 & 2.8 & 0.8 & 51.8 & 99 & 18 & 37 & oil \\
\hline Tanzania & savannah/desert & NA & NA & NA & 3.6 & 3.8 & 55 & 97 & 7 & 59 & pydropower \\
\hline Uganda & tropical & $1000-1500$ & NA & NA & 3.4 & -0.5 & 53 & 94 & 8 & 67 & hydropower \\
\hline
\end{tabular}

$\dagger$ Refer to Exhibit 6 for further information related to GDP and GNP.

$¥$ NA, not available.

$\S$ DRC, Democratic Republic of Congo.

112 • J. Nat. Resour. Life Sci. Educ., Vol. 32, 2003 
Exhibit 12. The relative ranking of the Nile riparian countries according to the Helsinki Rules.

\begin{tabular}{|c|c|c|c|c|c|c|c|c|c|}
\hline Indicator & Burundi & $\mathrm{DRC} \dagger$ & Egypt & Ethiopia & Kenya & Rwanda & Sudan & Tanzan ia & Uganda \\
\hline Country share in area of Nile basin, $\%$ & 9 & 7 & 1 & 3 & 6 & 8 & 2 & 5 & 4 \\
\hline Country water in contribution to the Nile & 2 & 6 & 8 & 1 & 3 & 2 & 7 & 4 & 5 \\
\hline Climate & 9 & 7 & 1 & 3 & 4 & 8 & 2 & 5 & 6 \\
\hline \multicolumn{10}{|l|}{ Utilization } \\
\hline Past & 5 & 5 & 1 & 4 & 5 & 5 & 2 & 5 & 3 \\
\hline Present & 4 & 4 & 1 & 3 & 4 & 4 & 2 & 4 & 4 \\
\hline \multicolumn{10}{|l|}{ Social needs } \\
\hline Life expectancy & 8 & 4 & 1 & 9 & 2 & 7 & 6 & 3 & 5 \\
\hline Infant mortality & 6 & 3 & 1 & 8 & 2 & 7 & 5 & 5 & 4 \\
\hline \multicolumn{10}{|l|}{ Economic needs } \\
\hline Income & 6 & 7 & 1 & 9 & 3 & 4 & 2 & 8 & 5 \\
\hline Total debt & 5 & 3 & 2 & 6 & 6 & 8 & 4 & 1 & 7 \\
\hline Total population 1990 & 9 & 3 & 1 & 2 & 6 & 8 & 5 & 4 & 7 \\
\hline Average annual growth of population $1987-2000$ & 5 & 6 & 8 & 6 & 1 & 2 & 7 & 3 & 4 \\
\hline Average annual growth of agriculture $1980-7$ & 5 & 3 & 4 & 9 & 2 & 6 & 7 & 1 & 8 \\
\hline Cereal imports & 9 & 4 & 1 & 2 & 5 & 8 & 3 & 6 & 7 \\
\hline Food production per capita, index, 1985-1988 & 3 & 4 & 2 & 5 & 5 & 6 & 5 & 5 & 1 \\
\hline Percentage of labor force in agriculture, $1985-1988$ & 1 & 7 & 9 & 6 & 5 & 2 & 8 & 4 & 3 \\
\hline Agriculture as percentage of GDP 1988 & 3 & 7 & 8 & 4 & 7 & 5 & 6 & 2 & 1 \\
\hline
\end{tabular}

$\dagger$ DRC, Democratic Republic of Congo.

Key:

Country share, $1=$ largest

Country water contribution, $1=$ greatest $\quad$ Life expectancy, $1=$ longest, $9=$ shortest

Climate, 1 = dry, 9 = wet

Past use, $1=$ oldest, 5 = newest
Total debt $(\%$ GDP), $1=$ largest debt, $8=$ smallest Total population, 1 = largest, $9=$ smallest Average annual population growth, $1=$ highest Average annual growth in agriculture, $1=$ highest
Cereal imports, $1=$ largest importer Food production index, $1=$ highest drainage area in each country; (ii) climatic conditions governing the basin; (iii) history of water utilization, up to present-day usages; (iv) economic and social needs for each basin country; (v) population; (vi) comparative costs of alternative means of satisfying the economic and social needs of each country; (vii) availability of other water resources to each basin country; and (viii) the avoidance of undue waste and unnecessary damage to other countries. Although these rules are generally accepted, they are nonbinding in international law. If applied to the Nile basin case, there is no doubt that Ethiopia, Sudan, and practically all the equatorial countries rank higher than Egypt on almost all variables, entitling them to a larger portion of the Nile water. This emphasizes the strong interrelation between politics and international water conflicts, whereby the politically and economically dominant country generally prevails and controls an international water resource. As such, the country that enjoys the largest percentage of the water does not necessarily have to be the most deserving, thus sacrificing the economic advancement, social development, and political stability of other countries in the basin.

\section{THE DECISION}

A delicate conflict over the equitable allocation of the Nile waters represents one of the most critical issues in the African continent. The relatively powerful and progressive Egypt has managed to dominate the basin by asserting its historical rights to exploit the Nile waters. The other countries remain politically unstable and suffer from famine and chronic malnutrition, limiting their ability toward social and economic development, as well as to devise comprehensive water schemes, and adopt water efficient technologies. Students are expected to research the topic through the set of questions in the Teaching Note. Then students must form a panel representing involved countries (advocating the positions of the different countries) and third-party mediators to hold negotiations. These negotiations should (i) alleviate tension through the for- mulation of a specific set of strategies catering for the economic, environmental, socio-political, and technical aspects of all countries within the watershed and (ii) take into consideration the countries' water demands and shortages.

\section{TEACHING NOTE}

\section{Case Objectives}

This case study presents an important issue in Africa, which may threaten the availability of even the most basic physical needs of water and food in the region. The case should allow students to:

- Become familiar with the water status in the Nile basin

- Understand the various underlying factors of the water-related conflict in the framework of historical quarrel, political instability, and proposed water development projects

- Recognize the interrelation between natural resources and political interplay

- Enhance their objectivity in tackling sensitive socio-political water resources issues

- Recognize international laws and regulations related to cross-boundary waters

- Define and evaluate implementation strategies for cooperation between conflicting countries in international river basin management

\section{Uses of the Case}

This case targets senior and graduate level students in natural and water resources management and environmental engineering and science; however, students in political sciences, social studies, agricultural sciences, or related fields may find the case equally beneficial. Students will utilize crucial decision-making skills to tie the scientific, social, and political components of the issue. The case-based on region-specific data, socio-economics, politics, and historical events-also provides students with an opportunity to evaluate water resources management in a water-scarce region. 


\section{Implementation of the Case}

Given the complex socio-political aspects of the region, it is helpful if students are introduced to the history of the Nile basin political conflict before being exposed to the case. Numerous books have been written in this regard and a great deal of information can be found on the Internet (Murakami, 1995; FAO, 1997; Inventory of Conflict and Environ., 1997; Karyabwite, 2000; Nile Basin Initiative, 2002). The case was used in a graduate-level course on environmental case studies and conflict resolution at the American University of Beirut. The class was composed primarily of environmental science students with diverse backgrounds (chemistry, geology, physics, civil engineering, ecosystem management, and environmental health). Invariably, the feedback of students was important and their input was used to improve on the case and refine certain questions. ${ }^{4}$

Case studies can be used in a variety of ways in a classroom setting (Herreid, 1994) ${ }^{5}$; however, the implementation should be appropriate to the background of the students and the objectives of the course. This particular case lends itself in role playing and should be first assigned as an outside reading (without the Teaching Note) before being discussed in class. After students become familiar with the case, they are divided into groups, each designated with the task of acquiring further information with respect to a particular country within the basin and to respond to the questions outlined in the Teaching Note. The case can then be analyzed over another 1 or 2 wk whereby students assume the role of opponents or supporters of the various views of each of the Nile basin countries. The Teaching Note would be shared with the students during or after the case discussion. An outside panel not as familiar with the case could be invited to listen to the debate and make a decision based on the arguments presented by the students. Role-playing offers the advantage of developing analytical skills, practicing public speaking, enhancing spontaneity, and promoting awareness of socio-economic, political, and cultural constraints.

\footnotetext{
${ }^{4}$ Our experience with the case spans over two semesters (in $2 \mathrm{yr}$ ). In the first semester, a group of students initiated the development of the case as part of their project assignment in a course on conflict resolution. During that semester, an initial draft was submitted to the instructor, who corrected the paper and introduced major changes to its content and structure. The group presented and tested the case with the rest of the class. The case was then modified by the instructor based on the class feedback and was used again the following year. In the second application, the case was distributed to the students as an outside reading with a set of well-defined questions to be answered, which allowed the students to further research the topic. The students were then divided into groups representing the various countries involved. The students' answers to the predefined questions as well as the class debate were used as another level of feedback to refine the case. In their evaluation of the case, the students felt that the case was highly informative and appropriate for the course; however, they concurred in both semesters that the case is complex and should be given more than $2 \mathrm{wk}$.

5 (i) Assigned as outside reading followed by a general class discussion with a decision that needs to be reached with the corresponding justification.

(ii) Written reports could be required for grading purposes; after correction of the reports, answers can be discussed in class in the context of actual events and what the final decision could be.

(iii) The case can be read in class (which would take about $3 \mathrm{~h}$; the case would be too long for a 1-h session) followed by either small group or whole class discussion of all or selected questions.

The latter approach requires the least amount of class time, but it also provides the least chance for students to reflect on the issues of the case.
}

\section{DISCUSSION QUESTIONS AND ANSWERS}

1. Waterbury (1997) states: "If the riparians would agree that the sole criterion for resolving conflicting demands would be strict application of a rule that highest economic returns per unit of water determine who receives each additional unit of water, and if the infrastructure is in place to store the water, then the problem would be greatly alleviated." Do you agree with Waterbury? Waterbury's formula is inapplicable in the case of the Nile basin because countries that are willing to pay may not be those that are in most need. This is best illustrated by Ethiopia, a country that suffers the largest water shortage and is incapable of competing with Egyptian buying power. Besides that, this rationale has its weaknesses since it overlooks basic ethical values, whereby the potable water rights of the Nile basin countries should be acknowledged, irrespective of their willingness or capability of buying water shares. This strategy if adopted will enhance the development of the richer country capable of acquiring the water, and will increase the dependence of the poorer countries on the richer ones for their basic food supply. Therefore, economic incentives should not be the only basis for allocation of water resources, largely due to the inevitable economic, social, and political discrepancies among the concerned parties.

2. How does Egypt defend its pattern of water usage? Can it initiate measures to decrease its current consumption? Egypt argues that it is unable to reduce its water consumption because:

- Its hydroelectric power supply will be affected

- It fears farmers' outrage, thus aims at avoiding collision with them

- It is currently doing its best by shifting from canals to underground pipes

- It needs reclaimed land to help diffuse population concentration along the Nile

On the other hand, various arguments have been put forth by the remaining countries claiming that Egypt can reduce its current use of the Nile's waters, namely by:

- Reducing the flow at the Aswan high dam and minimizing water losses

- Charging the farmers for water consumed in agriculture

- Adopting various efficiency measures such as wastewater reclamation, desalination, and shifting from water-intensive to water-extensive systems

- Stopping land reclamation, which leads to low water use efficiency

3. What measures must Ethiopia take to improve its current food and water shortages? Ethiopia is incapable of maintaining food production levels through the continued practice of traditional highland agricultural approaches. Therefore, Ethiopia must resort to developing alternative basins (such as the Abbay, Tekeze, and Baro Akobo) that have a promising potential for irrigation, hydropower production, and tourism. If Ethiopia manages to produce sufficient electricity, it may improve its energy base for industrial and urban development, if not sell hydroelectric power to other countries.

Ethiopia may need to exert pressure on downstream countries that may trigger their positive engagement in negotiations 
that aim at changing the status quo and gaining a more reasonable and unbiased basin-wide water distribution. Most importantly, Ethiopia needs to increase the awareness of its people, make them more involved in water issues, and encourage their active participation in both governmental and nongovernmental institutions that aim at enhancing the country's socio-economic progress (allAfrica.com, 1999).

4. What are the conflicting roles of economic growth and development with respect to water? What is the implication here? Although the growth in the use of water as an input to agriculture and industry will have measurable effects on water quality if not appropriately planned and monitored, the lack of such development also poses other, different threats. Without economic growth and development, population growth in the area will aggravate existing problems of poverty and food insecurity resulting in watershed degradation, water pollution, and the loss of native forests, wetlands, wildlife habitat, and biodiversity. The rural poor will continue to have little choice but to cultivate the often unsuitable steep uplands and overexploitation of natural resources to meet food and energy needs. Thus, Nile basin countries must proceed by balancing resource development for human use against the needs of the ecosystem.

5. Egypt prohibited Sudan and Ethiopia from developing water projects along the Nile within their territories and threatened to go to war with any country that will threaten the Nile water. Do you think that Egypt will initiate a war to protect its water share? The Egyptian government has long recognized upstream development of the Nile's waters as a potential national security threat and has stated its willingness to revert to military measures to secure its water supply. In August 1994, for example, Egypt planned and subsequently aborted an air raid on Khartoum in Sudan where a dam was being built. While confrontation over the Nile water is nothing new, it may yet be resolved diplomatically. Egypt now realizes that a war over water would be too costly in terms of manpower and resources, and also that the benefits of new agreements could be enormously important for Egypt's international standing, as well as for peace in the region. In addition, international laws prevent Egypt from implementing any military action, especially since it is the most downstream country and hence generally perceived as the least deserving of the largest proportion of the Nile waters.

6. Do you think that a comprehensive treaty that satisfies all Nile basin countries could be reached? What are the arguments that could be advanced by the countries to validate their right to more water? Conflicting interests between countries sharing the same river have long prevented the fair and equitable distribution of international waters. However, attempts at resolving this everlasting controversy produced comprehensive rules for addressing these pressing issues, the most common being the Helsinki and International Law Commission rules (Int. Law Assoc., 1967), which take into consideration several factors such as the history of water utilization, the availability of other water resources, in addition to the economic and social needs of countries, when distributing international waters in an equitable manner.

In real life cases, the dominant country in the basin has historically imposed a solution that best suits its interests. With no exception, this has been the case in the Nile basin, whereby Egypt, the basin's most powerful country both economically and politically, has always negotiated for settlements that best suited its own interests, often disregarding the needs of the other countries within the watershed. Egypt may have previously gotten away with its actions due to the inability of its upstream neighbors to develop major water projects on the Nile; however, with their economic development, along with an increased awareness regarding their natural water rights, Egypt is unlikely to escape the inevitable call to renegotiate the Nile water shares in a more equitable and effective manner. In this context, Exhibit 13 outlines major arguments voiced by Egypt, Ethiopia, and the other countries with respect to their right in acquiring larger shares of the Nile's flow.

7. What are the major environmental threats implicated by increasing water withdrawal from the Nile basin through the further construction of dams? The Aswan Dam in Egypt has provided ample evidence to portray the effects of constructing dams without adequate consideration of long-term environmental effects, for example (Miller, 1998):

- The yearly flooding that fertilized the Nile Delta with silt was ended, with silt accumulating in Lake Nasser. Moreover, since the nutrient-rich silt no longer reaches the river's mouth, Egypt's sardine, mackerel, shrimp, and lobster industries have almost disappeared, leading to the loss of nearly 30000 jobs.

- Agricultural land in the Nile Delta basin is now treated with commercial fertilizer at an annual cost greater than $\$ 100$ million to make up for the lost nutrients.

- Salinization has increased in the Delta's soil, offsetting three quarters of the gain in food production from the new, less productive land irrigated by water from the reservoir. The country presently loses around $10 \%$ of its annual crop production due to declining soil fertility, mostly because of increased salt content.

Exhibit 13. Main arguments voiced by countries claiming their rights to more water.

\begin{tabular}{|c|c|c|}
\hline Egypt & Ethiopia & Remaining nations \\
\hline $\begin{array}{l}\text { - The Nile has long been regarded as the cultural } \\
\text { symbol of the country }\end{array}$ & \multicolumn{2}{|l|}{$\begin{array}{l}\text { - Demand natural right to own waters } \\
\text { - Rank higher than Egypt when Helsinki Rules are applied }\end{array}$} \\
\hline - Argues that the 1959 agreement is irrevocable & \multicolumn{2}{|c|}{$\begin{array}{l}\text { - Invalidate the } 1959 \text { agreement and request its renegotiation, claiming equal shares must be distributed regardless of } \\
\text { population and agricultural needs }\end{array}$} \\
\hline $\begin{array}{l}\text { - Claims more rights over other countries due to its large } \\
\text { population growth rate and corresponding agricultural } \\
\text { expansion requirements }\end{array}$ & $\begin{array}{l}\text { - Has a population nearly the size of Egypt's and regards the } \\
\text { key to poverty reduction and food security is through the } \\
\text { development of its water resources }\end{array}$ & $\begin{array}{l}\text { - Require Nile waters for projects to enhance economic } \\
\text { and agricultural development to help sustain their } \\
\text { growing populations }\end{array}$ \\
\hline $\begin{array}{l}\text { - Maintains that Ethiopia can sustain itself solely through } \\
\text { rainfed agriculture }\end{array}$ & $\begin{array}{l}\text { - Has been witnessing successive drought induced famines } \\
\text { - Development projects will only use } 0.5 \text { billion cubic meters } \\
\text { of the river's annual flow }\end{array}$ & \\
\hline
\end{tabular}


Exhibit 14. Environmental threats in the Nile basin (Baechor et al., 2000).

\begin{tabular}{|c|c|c|c|}
\hline Land degradation & Water degradation & Biodiversity loss & Natural and man-made disasters \\
\hline $\begin{array}{l}\text { - Deforestation } \\
\text { - Erosion } \\
\text { - Riverbank and shoreline degradation } \\
\text { - Loss of fertility }\end{array}$ & $\begin{array}{l}\text { - siltation } \\
\text { - wetland destruction } \\
\text { - nutrient loads } \\
\text { - urban and industrial wastes } \\
\text { - eutrophication } \\
\text { - disease }\end{array}$ & $\begin{array}{l}\text { - bird species } \\
\text { - fish species } \\
\text { - large animal species } \\
\text { - exotic species and weeds } \\
\text { - domesticated plant species }\end{array}$ & $\begin{array}{l}\text { - flood } \\
\text { - drought } \\
\text { - refugee displacement } \\
\text { - accidents and spills }\end{array}$ \\
\hline
\end{tabular}

- Without the Nile's yearly sediment discharge, the Mediterranean Sea is eroding the delta and advancing inland, which further reduces agricultural productivity.

- Flooding the area of Lake Nasser uprooted 125000 people.

The evidence shows that dam construction poses significant environmental threats with far-reaching implications for a country's population, economy, and biodiversity. Exhibit 14 categorizes the major threats anticipated to arise from further weakly planned water quantity augmentation projects with respect to the principal types of resources: land, water, biological, and human.

However, arguments are faced by the many benefits presented by increased water quantity due to the Aswan dam. For example (Miller, 1998):

- The dam supplies almost a third of Egypt's electrical power - Lake Nasser can store at least 2 yr of the River's annual flow

- Year-round irrigation has increased food production because land that was previously cultivated once per year is capable of producing crops three times

- $4050 \mathrm{~km}^{2}$ of desert land has been brought under cultivation

8. What management measures must be promoted by the international committee to help resolve the Nile water issue? Devising a comprehensive Integrated Water Resource Management (IWRM) plan is inevitable for cooperation over water resources, which should involve negotiations among the involved parties to reach an agreement on equitable utilization and protection of basin's water resources. The IWRM plan would integrate options for sustainable water resources use and development at the watershed level, incorporating the various rival and contradictory issues of the Nile basin. Essential components include public participation, cross-border collaboration, coordination on land use management strategies, political will, and provision for financial, technical, and human support. In short, such a plan is to integrate environmental, technical, social, financial, and legal aspects, pertaining to the specific needs of the Nile basin countries. These measures can be translated into specific actions including (Gardiner, 2000):

- Increased emphasis on the roles of governments, NGOs, and local authorities in monitoring and enforcing both national and international regulations regarding water quality and equitable allocation, as well as overtly supporting trans-boundary collaboration, promoting funds and awareness and capacity building, and encouraging community involvement.

- Formulation of goals by independent riparian governments for the involvement of inhabitants, defining their rights, responsibilities, and roles within an extensive institutional framework for contributive planning and management at various levels and across sectors.

- Adoption of water management strategies that promote a decrease in the demand for water and enhance opportunities to increase its supply. For example, demand could be decreased by controlling population growth, rationing the water, increasing public awareness with respect to the scarcity of water resources, charging farmers for water, and enhancing efficient water use especially in agriculture (drip irrigation, shift to drought resistant and salinity resistant crops, shift from open drainage to closed pipes). Public-private planning should be conducted and implementation and management processes adopted in consultation with local water users to decide on the most beneficial approach, ensuring that the poorest are fully reflected in the decision making through improved communication of access rights and frameworks for community involvement. With respect to augmenting supply, efforts can focus on wastewater reclamation, saltwater desalination, as well as rainwater harvesting, where found feasible.

- Collection of independent baseline data about the physical status of surface and groundwater reservoirs in the riparian countries, promoting research, modeling and monitoring of water resources, identifying areas with threatened water supplies or where human conflict or natural pressure exist.

- Enhancement of knowledge and information exchange through education, information exchange, and training to allow the involvement of poor, disadvantaged communities, local authorities, and NGOs. Granting the residents a certain degree of responsibility allows them to be more efficient and aware users, in addition to reinforcing local monitoring and regulating of water resources.

\section{ACKNOWLEDGMENTS}

Special thanks are extended to the U.S. Agency for International Development for its support to the Water Resources Center at the American University of Beirut.

\section{REFERENCES}

allAfrica.com. 1999. Water and Politics on the Nile [Online]. Available at http://www.hewett.norfolk.sch.uk/curric/NEWGEOG/Africa/waterwa6.htm (accessed 15 Mar. 2002; verified 12 Sept. 2003).

Baecher, G.B., R. Anderson, B. Britton, K. Brooks, and J. Gaudet. 2000. Environmental trans-boundary opportunities and constraints for the Nile Basin, U.S. Agency for International Development, Washington, DC.

Beschorner, N. 1992. Water and instability in the Middle East. The International Institute for Strategic Studies, London.

British Broadcasting Center. 1999. Africa's potential water wars [Online]. Available at http://news.bbc.co.uk/hi/english/world/africa/newsid_ 454000/454926.stm (accessed 29 Apr. 2002; verified 12 Sept. 2003).

Food and Agriculture Organization of the United Nations. 1997. Irrigation potential in Africa: A basin approach [Online]. Available at http://www. fao.org/docrep/W4347E/w4347e00.htm\#Contents (accessed 25 Apr. 2002; verified 12 Sept. 2003). FAO, Rome, Italy.

Food and Agriculture Organization of the United Nations. 2000. AQUASTAT: FAO's Information System on Water and Agriculture [Online]. Available at http://www.fao.org/ag/agl/aglw/aquastat/dbase/index2.jsp (accessed 28 Feb. 2003; verified 12 Sept. 2003). FAO, Rome, Italy. 
Gardiner, R. 2000. Freshwater: A global crisis of water security and basic water provision [Online]. Available at http://www.earthsummit2002.org/ es/issues/freshwater/freshwater.rtf (accessed 29 Apr. 2002; verified 12 Sept. 2003).

George, A. 1998. Friction generated over Nile waters share out: Egypt's irrigation scheme. Petroleum Times Energy Report 18(7):4.

Gleick, P. 2000. Water conflict chronology [Online]. Available at http://www.worldwater.org/conflict.htm (accessed 29 Apr. 2002; verified 12 Sept. 2003). Pacific Inst., Oakland, CA.

Herreid, C.F. 1994. Case studies in science: A novel method of science education. J. of College Science Teaching Feb:221-229.

Howell, P.P., and J.A. Allan. 1994. The Nile sharing a scarce resource. Cambridge Univ. Press, London.

International Law Association. 1967. The Helsinki rules on the uses of the waters of international rivers [Online]. Available at http://www.internationalwaterlaw.org/IntlDocs/Helsinki_Rules.htm (accessed 25 Apr. 2002; verified 12 Sept. 2003). Int. Law Assoc., London.

Inventory of Conflict and Environment. 1997. Case number 1. Nile River dispute [Online]. Available at http://www.american.edu/projects/mandala/TED/ice/nile.htm (accessed 15 Mar. 2002; verified 12 Sept. 2003). American Univ., Washington, DC.

Karyabwite, D. 2000. Water sharing in the Nile River valley [Online]. Available at http://www.grid.unep.ch/activities/sustainable/nile/nilereport.pdf (accessed 25 Apr. 2002; verified 12 Sept. 2003). United Nations Environment Programme, Geneva, Switzerland.

Miller, G.T. 1998. Water. p. 488-513. In Living in the environment: Principles, connections and solutions. 10th ed. Wadsworth Publ. Co., New York.
Murakami, M. 1995. Managing water for peace in the Middle East: Alternative strategies [Online]. Available at http://www.unu.edu/unupress/unupbooks/80858e/80858E00.htm\#Contents (accessed 25 Apr. 2002; verified 12 Sept. 2003). United Nations Univ. Press, New York.

Nile Basin Initiative. 2002. Introduction to the Nile River Basin [Online] Available at http://www.nilebasin.org/IntroNR.htm (accessed 15 Apr. 2002). Nile Basin Initiative, Entebbe, Uganda

Nileriver.com. 2001. Sustaining water, easing scarcity: The case of the Nile River Basin [Online]. Available at http://www.nileriver.com/nile/Articles/article002.htm (accessed 15 Apr. 2002; verified 12 Sept. 2003).

Population Action International. 2001. Why population matters to freshwater availability [Online]. Available at http://www.populationaction.org/resources/factsheets/factsheet 6.htm (accessed 29 Apr. 2002; verified 12 Sept. 2003). Population Action International, Washington, DC.

Samuelson, P.A., and W.D. Nordhaus. 1998. Measuring economic activity. p. 390-410. In Economics. 16th ed. McGraw-Hill, Boston, MA.

Varis, O. 2000. The Nile Basin in a global perspective: Natural, human, and socioeconomic resource nexus. Water International 25(4):624-637.

Waterbury, J. 1997. Between unilateralism and comprehensive accords: Modest steps towards cooperation in international river basins. Water Resour. Dev. 13(3):279-289.

Whittington, D., and G. Guariso. 1983. Water management models in practice: A case study in water allocation for agricultural expansion in Egypt and Sudan. p. 125-150. In P. Beaumount and K. Mclachlan (ed.) Agricultural development in the Middle East. John Wiley \& Sons, New York. 